\title{
Spatial patterns of illegal resource extraction in Kibale National Park, Uganda
}

\author{
CATRINA A. MACKENZIE ${ }^{1 *}$, COLIN A. CHAPMAN ${ }^{2,3}$ AND RAJA SENGUPTA ${ }^{1,2}$ \\ ${ }^{1}$ Department of Geography, McGill University, 805 Rue Sherbrooke Ouest, Montreal, Quebec H3A 2K6, Canada, ${ }^{2}$ McGill School of Environment \\ and Department of Anthropology, McGill University, Montreal, Quebec H3A 2T7, Canada and ${ }^{3}$ Wildife Conservation Society, Bronx, \\ New York, NY, USA \\ Date submitted: 26 July 2010; Date accepted: 13 January 2011; First published online: 21 June 2011
}

\section{SUMMARY}

Conservation policy typically excludes people from national parks and manages encroachment by law enforcement. However, local people continue to extract resources from protected areas by boundary encroachment and poaching. This paper quantifies the patterns of illegal resource extraction from Kibale National Park in Uganda, the demand for Park resources by communities bordering the Park, and examines whether designated resource access agreements reduce illegal extraction. Sections of the Park boundary were examined and human entry trails, wood extraction, livestock grazing, and animal poaching signs were quantified. Levels of illegal extraction were compared with the demand for and admitted illegal access to resources inside the Park, collected in a survey of households located near the Park. Extraction was also compared between villages with and without negotiated resources access agreements. The most wanted and extracted resource from the Park was wood for fuel and construction. Implementation of resource access agreements with local community associations was found to be an effective means of reducing illegal extraction, but only if the association members profited from the agreement.

Keymords: access agreements, conservation policy, human disturbance, national park, resource extraction, Uganda

\section{INTRODUCTION}

Biodiversity conservation is often characterized by two polarized narratives: the 'parks' position looks to exclude people from protected areas (PAs) (Terborgh \& van Schaik 2002), and manages encroachment by law enforcement, whereas the 'people' position demands access and management rights for local residents (Neumann 1998; Adams \& Hulme 2001). The 'parks' position, alternatively known as 'fences and fines' or 'fortress conservation' (Neumann

*Correspondence: Catrina MacKenzie e-mail: catrina.mackenzie@ mail.mcgill.ca
1998; Brockington 2002), developed from the colonial creation of PAs in Africa (Neumann 1998; Oates 1999) and the American 19th century environmental protection movement (Brockington 2002). The 'parks' position prioritizes the intrinsic value of biodiversity (Adams et al. 2004) and advocates top-down management of conservation areas (Buscher \& Wolmer 2007). The 'people' position developed from social injustices resulting from PA creation, such as forced eviction (Brockington \& Igoe 2006; Cernea \& SchmidtSoltau 2006), human wildlife conflict (Treves \& Karanth 2003) and losses incurred by communities living adjacent to PAs (McNeely 1993; Adams \& Infield 2003), as well as resistance by communities to the exclusionary 'parks' position (Hutton et al. 2005). To counter these injustices, community based conservation (CBC) was introduced (Adams \& Hulme 2001), which advocated integrated conservation and development (Barrett \& Arcese 1995), direct community management of resources (Child 2004) and at least negotiated access to resources (Barrow \& Murphree 2001). In return, communities help protect the park from illegal activities (Adams \& Hulme 2001; Archibald \& Naughton-Treves 2001; Chhetri et al. 2003; Child 2004).

Either extreme in the people or parks arguments minimizes the interdependency between PAs and local people (Redford et al. 2006). Exploitation of the park purely for resource extraction would lead to the decline of critically endangered species, loss of ecosystem services for local communities and potentially loss of tourist revenues (Naughton-Treves et al. 2005; Burgess et al. 2007). Fears that CBC prioritizes development over conservation have led to resurgence in protectionist discourse (Oates 1999; Terborgh \& van Schaik 2002; Hutton et al. 2005) and for more critical assessment of CBC (Buscher \& Wolmer 2007). Ideally, conservation policy needs to consider all PA stakeholders: conservation organizations that value the protection of biodiversity and look to protect carbon sinks to combat global warming (Naughton-Treves et al. 2005; FACE the Future [Forest Absorbing Carbon Dioxide Emissions] 2011), conservation authorities and local governments who need the tourists and foreign exchange that PAs can attract (Adams \& Infield 2003), and local people who need resources inside PAs to support subsistence livelihoods (Naughton-Treves et al. 2007).

Conservation policies in East Africa have favoured the 'parks' approach, however, people continue to illegally extract 
resources from PAs (Robbins et al. 2006; Holmes 2007). Trees are used as fuel wood for cooking, and heating (NaughtonTreves et al. 2007), protected grasslands are coveted by livestock herders, especially in times of drought and as pasture land becomes scarce (Neumann 1998; Infield et al. 1993; Kideghesho et al. 2007), and wild animals are hunted for meat (Neumann 1998; Chapman et al. 2006). Rural households depend on tropical forests for craft materials, medicinal plants, and as places to put beehives for honey production (Adams \& Infield 2003; Mbile et al. 2005; Bleher et al. 2006). Lack of access to PAs requires local residents to find or procure these resources elsewhere, which can be costly (Emerton 1999). However, illegal extraction of natural resources, and wildlife poaching, can lead to loss of habitat and further species endangerment (Chapman et al. 2006), resulting in the productive practices of local communities being perceived as threats to conservation (Mbile et al. 2005).

Studies have measured human disturbance inside PAs (Barve et al. 2005; Bleher et al. 2006; Baranga 2007; Olupot et al. 2009); however, most focused on ecological conservation by monitoring extraction without linking the drivers of disturbance to the productive practices of local communities. Alternatively, most social studies on conservation management rely on attitudes of local people towards PAs without linking these attitudes to measured illegal resource extraction (Infield 1988; Gillingham \& Lee 1999; Mugisha 2002; Gadd 2005; Mbile et al. 2005; Kideghesho et al. 2007; Hartter \& Goldman 2011). These studies link the demand for PA resources with socioeconomic factors such as population density (Burgess et al. 2007), household well-being (Infield 1988; Gillingham \& Lee 1999), education (Kideghesho et al. 2007), and enforcement capacity (Abbot \& Mace 1999).

This research does not try to explain the drivers of demand for resources, but aims to describe the patterns of measured illegal resource extraction from Kibale National Park in Uganda, link this extraction to the stated demand for Park resources, and investigate if negotiated resource access agreements reduce illegal extraction from the Park.

\section{METHODS}

\section{Study site}

Kibale National Park (KNP) is a $795 \mathrm{~km}^{2}$ protected mixed evergreen forest and savannah grassland located in western Uganda (Fig. 1). Prior to $1993 \mathrm{KNP}$ was a game corridor and forest reserve, selectively used for logging and exotic tree plantations (Struhsaker 1997). In 1971, a 15-year long war started, during which $c .55000$ people settled inside the forest reserve and game corridor (Naughton-Treves 1999). After the war, the Uganda Forest Department reclaimed forest reserves throughout Uganda, evicting approximately 35000 people from Kibale Forest Reserve and Game Corridor (Feeney 1998; Naughton-Treves 1999), although estimates of the actual number evicted vary greatly (Chapman \& Lambert

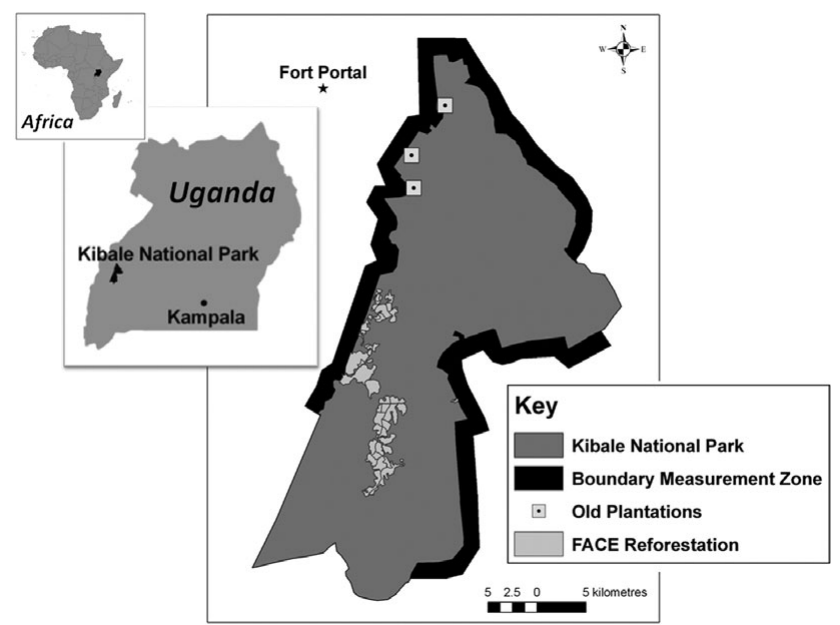

Figure 1 Location and diagrammatic map of Kibale National Park, Uganda. Old Plantations: exotic tree plantations created when the park was a forest reserve. FACE Reforestation: areas where FACE foundation has been planting indigenous trees for carbon sequestration.

2000). In 1993 Kibale became a national park. Evictees were eventually resettled far from KNP (Feeney 1998) therefore few current residents around KNP personally experienced eviction (Hartter \& Goldman 2011).

Conservation policy, defined through government legislation (Uganda Wildlife Statute 1996) is implimented by the Uganda Wildlife Authority (UWA). The core policy is exclusion, tempered by limited CBC, such as access agreements for specific resources (Chhetri et al. 2003), conservation education and sharing $20 \%$ of Park entrance fees to benefit people living next to the Park (Archibald \& Naughton-Treves 2001). UWA also partner with FACE the Future (Forest Absorbing Carbon dioxide Emissions), to reforest areas cleared by settlers (FACE the Future 2011), sometimes employing over 300 people to plant indigenous trees.

There are two forms of permitted resource access: resource access agreements (RA) and memoranda of understanding (MOU). RAs are legal agreements entered into by an association. In return for access, members promise to protect the Park by managing their own activities so as not to endanger animals, by reporting unauthorized people inside the Park and by helping to sensitize other villagers about conserving KNP. Current agreements permit keeping beehives in the Park (four), collection of craft materials (one), and fishing (two). In the past there were also agreements for firewood and/or NTFPs collection (three), watering cattle (one) and picking wild coffee (one), but these were discontinued due to the exhaustion of the resource (two firewood), association members caught in non-compliance of Park rules (one cattle watering and one NTFP), or because the association that had entered the agreement was disbanded (one wild coffee). In the 
seven active agreements, association members typically came from one to seven villages.

Communities around KNP are primarily subsistence agriculturalists from two dominant ethnic groups: Batooro to the north and Bakiga to the south. Between 2000 and 2006, UWA found 233 poaching signs and 272 signs of encroachment while on patrols inside KNP (PAWAR [Protected Area Watch for the Albertine Rift] 2009). Although patrol data can be biased by patrol location and intensity (Gavin et al. 2010) this does indicate that violations of Park rules persist. In a survey of residents close to KNP, $31.7 \%$ of people admitted entering the $\mathrm{PA}$ to gather resources (Mugisha 2002).

Although official permission to do this research had been provided at the national level, written authorization was also sought from the Regional District Commissioner and District Chairperson in the three districts where we collected data, and from the Sub-county and Village Chairpersons responsible for the 25 villages in our study. The Sub-county Chairpersons provided lists of villages located next to the Park, from which we chose our study villages. Our village selection was based on village members holding and/or cultivating land directly adjacent to the Park and geographic location; we chose an approximate spacing between village centres of five kilometres to evenly distribute the study villages along the $128 \mathrm{~km}$ of the boundary measurement zone (Fig. 1).

\section{Field methods}

Studies to measure human disturbance in tropical protected forests in India, Kenya and Uganda (Barve et al. 2005; Bleher et al. 2006; Baranga 2007; Olupot et al. 2009), recommended measuring trees cut for any purpose (all sites), signs of poaching (two sites), evidence of burning (two sites), in-park cultivation (three sites), pits to saw timber (one site), livestock grazing (four sites), charcoal-making (two sites) and extraction of a wide range of non-timber forest products (three sites).

Using a method developed from a study in Bwindi Impenetrable National Park, Uganda (Olupot et al. 2009), an observational transect $600-850 \mathrm{~m}$ in length was conducted along the boundary between each village and the Park. The boundary was approached via a village path or through cultivated land. Human entry trails into the Park were counted as a measure of access for resource extraction. Each trail was followed to its terminus, as determined by our Ugandan field assistants, unless the trails were created for research or UWA patrols, as confirmed by UWA. While walking the boundary and trails, we recorded poaching signs (snares and pit-fall traps), the number and species of grazing livestock inside the Park, the number of charcoal-making operations in or directly adjacent to the Park, boundary encroachment for cultivation, and evidence of fire inside the Park. We counted harvested trees, measured the diameter at the cut location and where possible, skilled assistants identified the species of tree and approximately how long ago harvesting had occurred. We recorded resource extraction within $5 \mathrm{~m}$ either side of the trail, but found that extraction quickly diminished within $3 \mathrm{~m}$. Since effective boundary demarcation has been correlated with effective PA management (Bruner et al. 2001), we also noted whether any harvested trees had been planted to demarcate the boundary.

Household surveys were carried out in all 25 villages to quantify the demand and admitted extraction of specific resources from the Park. Resource extraction is illegal so responses about extraction were prone to non-response and social undesirability biases (St John et al. 2010). Innovative methods, such as the randomized response technique (Solomon et al. 2007; St John et al. 2010) and the nominative technique (St John et al. 2010) have been tried to capture illegal extraction behaviours and to account for these biases. So far, randomized response has been the most successful, but requires more survey time, larger sample size, increased enumerator training and may result in respondents thinking they are being tricked (Gavin et al. 2010).

Given the logistic challenge of reaching 25 villages, we opted for direct questioning, but attempted to identify an upper bound to actual levels of extraction by asking, 'which Park resources would you like to have access to?', while capturing a lower bound asking about admitted extraction from the Park. We employed a format that empathized with the respondent for the later question, as this can elicit a more honest response (Blair et al. 1977): 'People need to survive and sometimes the Park has the resource we need to survive. For the following resources, how often do you get them from the Park: never/rarely/sometimes/often/ always?' Participants were specifically asked about access for beehive placement, and extraction of firewood, construction poles, exotic trees, medicinal plants, grasses, water, wild coffee, bushmeat and fish, although respondents were encouraged to report any other resources they wanted from the Park.

No sampling frame existed for the villages, so all households were mapped while noting the construction standard of primary dwellings. The number of households per village ranged from 41 to 242 with $64 \%$ of villages having less than 100 households, $20 \%$ having 100 to 150 households and the remaining $16 \%$ having over 150 households. Within each village, 24 households were surveyed $(10 \%$ to $59 \%$, average sampling error $=13 \%$ ) representing $24 \%$ of all households in all study villages (596 of 2480 , sampling error $=3.57 \%$ ). Households were chosen by random stratified sampling, with stratification based on house construction standard (Hartter 2009), a proxy for household wealth. Although stratification could have been done against other factors, such as household size, distance from the Park or education attained, poorer households are more dependent on natural resources and are least likely to be represented in surveys (Scoones 1995). The survey was administered in July and August 2009 by four Ugandan field assistants, three men and one woman, in two local languages (Rutooro and Rukiga). Since literacy rates in the region are low, a verbal informed consent was used at the start of the 1.5 hour survey. 
Income generating activities may be linked to resource extraction, so respondents were asked if household members owned a woodlot, made money from charcoal-making, brick making or firewood selling and the quantity of livestock they owned. Other potential incentives for resource extraction, such as wild animals raiding crops or if the household had experienced food insecurity in the prior year, were also recorded. Since there have been fuel efficient stove projects around KNP, we inquired if the household had an energysaving stove and how much their firewood usage had reduced as a result. Finally, respondents were asked to rate their perceived benefit of taking resources from the Park, structured as a five point scale.

A list of associations having resource access agreements was provided by UWA. The Lake Kabalika Fishing Association was located in the far south-western corner of the Park, outside the boundary measurement zone of this study, and was therefore excluded from this research. The leaders of all other resource access associations were interviewed to confirm the scope and financial benefit of the agreement. Records of species and quantity of permitted exotic tree extraction from the Park were also provided by UWA.

\section{Analysis}

Data were corrected for sanctioned activities by removing legally harvested trees, and entry trails for valid resource access agreements, FACE operations, UWA patrols and research. Identified species were classified as exotic or indigenous and to successional stage (Zanne \& Chapman 2005; NaughtonTreves et al. 2007; Lebamba et al. 2009; Omeja et al. 2009). Michaelis Menten Means extrapolation and Mao Tau species accumulation curve (Colwell 2009) were used to estimate species richness inside the boundary of KNP. Collecting data adjacent to villages may have resulted in more measured disturbance than if the entire boundary had been measured. However with the exception of tea plantations in the north, it is rare to find locations with no human habitation within a few hundred metres of the Park boundary.

Since other factors outside the scope of this paper, such as livelihood assets, income opportunities and access to resources outside the Park, could also affect measured levels of extraction, we limited the analysis to correlations aimed at identifying possible trends that can be tested in a future multi-variate analysis as other co-factors become available. All village-scale variables were normally distributed and suitable for parametric analysis (Pearson correlations, r), with the exception of poaching signs, number of livestock grazing and illegal exotic tree species extraction where nonparametric analysis was employed (Spearman correlations, $\mathrm{r}_{\mathrm{S}}$ ). Household-scale variables were not normally distributed, so non-parametric analysis was used (Kendall Tau-b correlations, $\mathrm{r}_{\mathrm{K}}$ ). With the exception of inherently spatial correlations (straight line distance) and correlations between ordinal variables, correlation residuals were tested for spatial autocorrelation using Moran's I ( $p<0.05)$, and, if significant, a simultaneous autoregressive correction (Anselin 1988) was applied.

To minimize the potential for local villagers to be punished for illegal extraction as a result of this research (Robbins et al. 2006), we used kriging interpolation to rasterize data to a $1000 \mathrm{~m}$ grid and then re-sampled the result to a resolution of $30 \mathrm{~m}$ within the boundary measurement zone (Fig. 1). This permitted the visualization of high and low extraction areas, without specifically identifying which village had participated.

Measured illegal extraction could not be attributed to any one household or any survey household, however since the independent unit of illegal extraction measurement is the village, we assumed that survey data are representative of village conditions and could be averaged to the village scale for comparison with observed extraction. For statistical purposes, disturbance data from each boundary transect and entry trails from that transect were summed, normalized by the length of boundary sampled, and treated as an independent data point to be compared with survey data from the adjacent village. Measured extraction of trees and illegal entry trails were tested for spatial clustering using Moran's I and if clustered, data were checked for high and low value clustering using GedisOrd General G (Haining 2003). Signs of grazing and poaching were not normally distributed so could not be tested for spatial clustering using spatial statistics, as small sparse samples are sensitive to non-normality (Griffith \& Layne 1999).

\section{RESULTS}

\section{Patterns of illegal extraction}

Illegal extraction was recorded along $19.5 \mathrm{~km}$ or $15.2 \%$ of the boundary measurement zone (Fig. 1), from May to August 2008 and in June 2009 (Table 1, Fig. 2).

\section{Trees}

A total of 3035 trees and shrubs were harvested along the boundary zone, $87 \%$ of which were identified to species (Table 2); $51 \%$ of trees were indigenous, while $36 \%$ were exotic. The estimated species richness was 66 , indicating harvested species represented $88 \%$ of the species existing along the boundary. Indigenous species were $25 \%$ old growth, $9 \%$ mid-successional and $67 \%$ early successional. Ninety per cent of the harvest measured $<20 \mathrm{~cm}$ in diameter (Table 3), suggesting these trees were taken for firewood and construction poles, while the remaining $10 \%,>20 \mathrm{~cm}$ in diameter, would likely have been taken for timber or charcoalmaking.

Of 3035 trees and shrubs harvested, 2794 were illegal. On average, 144 trees or shrubs were illegally harvested per $\mathrm{km}$ of boundary. Although tree extraction was found adjacent to all 25 villages, the spatial distribution (Fig. $2 a$ ) was not random (Moran's $I=0.11, Z_{\text {score }}=3.25$ ), with high levels of extraction clustered along the western boundary (GetisOrd General $G=8.61, Z_{\text {score }}=2.74$ ), possibly owing to the proximity of Fort Portal (Fig. 1), a major urban centre (Ahrends et al. 2010). Fifty-one per cent of extracted trees 
Table 1 Human disturbances found along the boundary of Kibale National Park, Uganda. Number recorded: ${ }^{1}$ per village boundary, ${ }^{2}$ per tree, ${ }^{3}$ per trail and ${ }^{4}$ per village where the activity occurred.

\begin{tabular}{lcccr}
\hline \hline Human disturbance & Mean $( \pm$ SD) & $\begin{array}{c}\text { Percentage of villages } \\
\text { where disturbance } \text { was } \\
\text { found }(\boldsymbol{n}=25)\end{array}$ & $\begin{array}{c}\text { Total recorded for } \\
\text { 19.5 } \text { km of boundary }\end{array}$ & $\begin{array}{c}\text { Per km of boundary } \\
\text { measured }\end{array}$ \\
\hline Number of harvested trees & $112( \pm 99)^{1}$ & $100 \%$ & 2794 & 143.6 \\
Basal area harvested $\left(\mathrm{m}^{2}\right)$ & $0.15( \pm 4.6)^{2}$ & - & 46 & 2.4 \\
Number of boundary trees & $26.8( \pm 49.8)^{1}$ & $64 \%$ & 726 & 37.3 \\
Number of illegal trails & $2.8( \pm 3.7)^{1}$ & $60 \%$ & 73 & 3.8 \\
Length of trails (m) & $63.5( \pm 56.7)^{3}$ & - & 4637 & 238.3 \\
Number of poaching signs & $0.89( \pm 2.8)^{1}$ & $24 \%$ & 24 & 1.2 \\
Number of grazing livestock & $13.8( \pm 41.9)^{1}$ & $36 \%$ & 373 & 19.0 \\
Charcoal making & $1.0( \pm 0)^{4}$ & $20 \%$ & 5 & 0.3 \\
Boundary encroachment & $1.0( \pm 0)^{4}$ & $4 \%$ & 1 & 0.1 \\
Fire inside park & $1.0( \pm 0)^{4}$ & $16 \%$ & 4 & 0.2 \\
\hline \hline
\end{tabular}

Figure 2 Patterns of illegal extraction along the boundary of Kibale National Park, Uganda (a) illegal tree basal area harvested,

(b) illegal entry trails, $(c)$ poaching signs and (d) in-park livestock grazing.
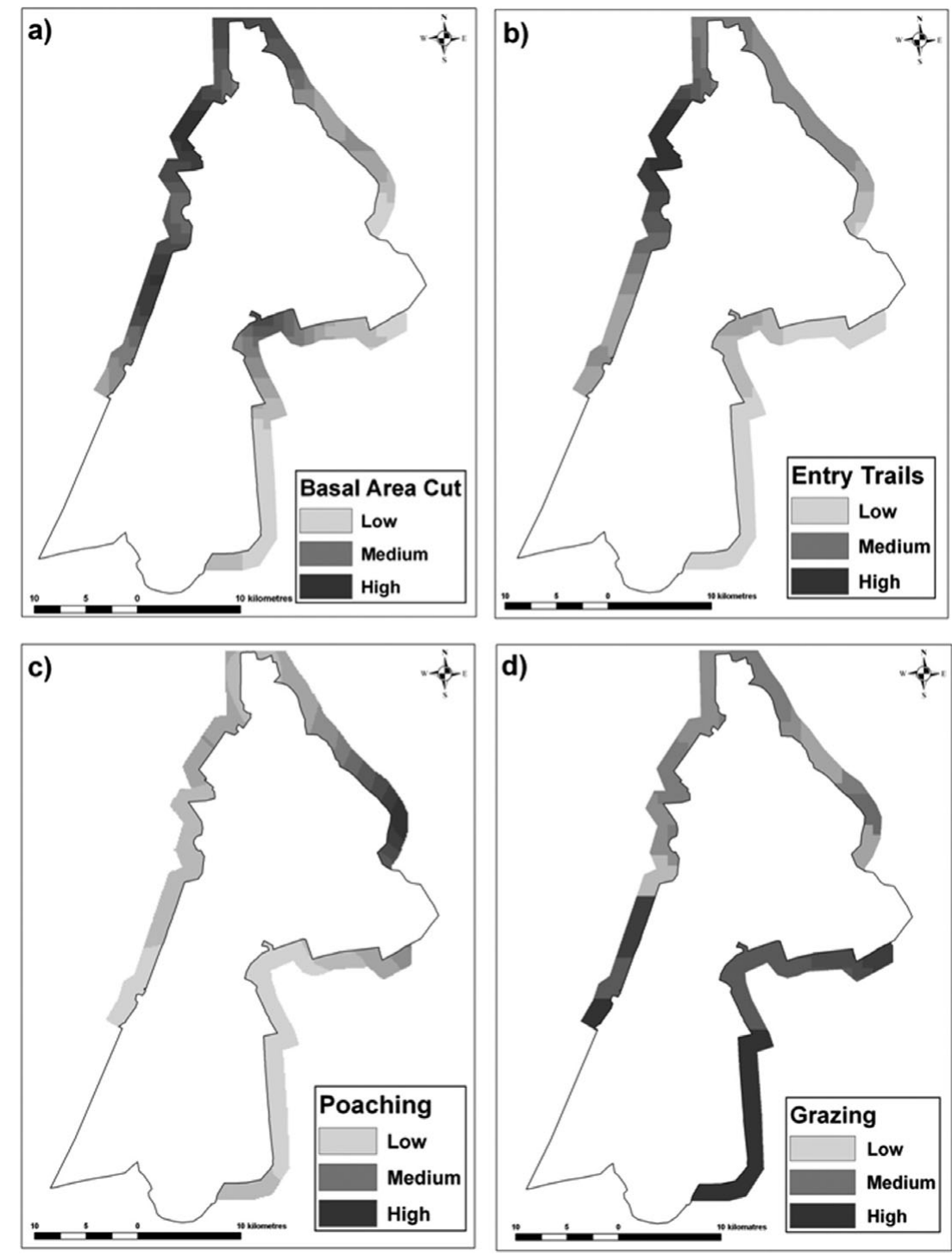

were found along entry trails with most recorded within $200 \mathrm{~m}$ of the boundary (also see Olupot et al. 2009). Twentyfour per cent of the harvested trees were boundary trees planted by UWA. Across the 25 villages, illegal extraction of all trees was greater where boundary tree harvesting was high ( $\mathrm{r}=0.738, p<0.001,25$ villages $)$. 
Table 2 Legally and illegally harvested tree species recorded on $19.5 \mathrm{~km}$ of boundary sampling done in Kibale National Park, Uganda. $\mathrm{ES}=$ early successional, $\mathrm{MS}=$ mid-successional, $\mathrm{OG}=$ old growth, $\mathrm{EX}=$ exotic. Only species with harvested basal area $>0.1 \mathrm{~m}^{2}$ have been included.

\begin{tabular}{|c|c|c|c|c|c|c|}
\hline Species & $\begin{array}{l}\text { Number } \\
\text { harvested }\end{array}$ & $\begin{array}{c}\text { Diameter }(\mathrm{cm}) \\
(\text { mean } \pm S D)\end{array}$ & $\begin{array}{c}\text { Total basal area } \\
\text { harvested }\left(\mathrm{m}^{2}\right)\end{array}$ & $\begin{array}{c}\text { Time since cut } \\
\text { (months) } \\
\text { (mean } \pm S D)\end{array}$ & Form & Stage \\
\hline Eucalyptus spp. & 845 & $12.87 \pm 8.88$ & 16.219 & $18.07 \pm 22.12$ & Tree & EX \\
\hline Albizia grandibracteata & 120 & $9.94 \pm 12.9$ & 2.487 & $12.17 \pm 18.43$ & Tree & ES \\
\hline Parinari excelsa & 6 & $55.23 \pm 36.4$ & 1.958 & $20.63 \pm 26.2$ & Tree & OG \\
\hline Olea melmitschii & 6 & $53.69 \pm 36.83$ & 1.891 & $38.13 \pm 39.78$ & Tree & MS \\
\hline Ficus spp. & 49 & $14.20 \pm 15.01$ & 1.625 & $10.38 \pm 16.0$ & Tree & $\mathrm{ES}$ \\
\hline Prunus spp. & 68 & $11.31 \pm 11.78$ & 1.413 & $10.64 \pm 10.95$ & Tree & $\mathrm{ES}$ \\
\hline Funtumia spp. & 84 & $11.15 \pm 9.18$ & 1.369 & $7.45 \pm 8.63$ & Tree & ES \\
\hline Macaranga schmeinfurthii & 57 & $10.8 \pm 12.64$ & 1.224 & $6.57 \pm 6.32$ & Tree & $\mathrm{ES}$ \\
\hline Acrocar Pearsonus sp. & 19 & $21.31 \pm 18.41$ & 1.157 & $17.16 \pm 17.0$ & Tree & $\mathrm{EX}$ \\
\hline Markhamia spp. & 135 & $7.9 \pm 5.64$ & 0.997 & $10.62 \pm 9.12$ & Tree & OG \\
\hline Celtis spp. & 74 & $9.69 \pm 7.07$ & 0.832 & $15.11 \pm 16.71$ & Tree & $\mathrm{ES}$ \\
\hline Strombosia scheffleri & 24 & $10.04 \pm 18.14$ & 0.785 & $13.08 \pm 11.72$ & Tree & OG \\
\hline Maesa lanceolata & 112 & $8.61 \pm 3.43$ & 0.754 & $12.72 \pm 11.48$ & Tree & $\mathrm{ES}$ \\
\hline Sapium spp. & 54 & $10.29 \pm 8.19$ & 0.728 & $7.86 \pm 7.63$ & Tree & ES \\
\hline Spathodea campanulata & 77 & $9.26 \pm 5.83$ & 0.722 & $10.42 \pm 6.14$ & Tree & ES \\
\hline Millettia dura & 70 & $10.19 \pm 5.28$ & 0.721 & $11.33 \pm 16.05$ & Tree & ES \\
\hline Bridelia micrantha & 81 & $9.02 \pm 5.3$ & 0.694 & $8.94 \pm 12.90$ & Tree & $\mathrm{ES}$ \\
\hline Senna spectabilis & 128 & $7.42 \pm 3.52$ & 0.677 & $4.29 \pm 3.83$ & Tree & $\mathrm{EX}$ \\
\hline Neoboutonia sp. & 33 & $13.54 \pm 5.95$ & 0.564 & $7.11 \pm 11.29$ & Tree & $\mathrm{ES}$ \\
\hline Pseudospondias microcarapa & 6 & $28.33 \pm 18.75$ & 0.516 & $10.67 \pm 9.85$ & Tree & OG \\
\hline Dombeya mukole & 47 & $9.10 \pm 5.93$ & 0.432 & $11.34 \pm 10.5$ & Tree & OG \\
\hline Polyscias fulva & 4 & $27.61 \pm 24.74$ & 0.384 & $34.25 \pm 57.2$ & Tree & $\mathrm{ES}$ \\
\hline Dracaena steudneri & 36 & $10.46 \pm 4.33$ & 0.361 & $2.31 \pm 2.39$ & Tree & $\mathrm{ES}$ \\
\hline Nemtonia buchananii & 31 & $9.86 \pm 7.26$ & 0.361 & $8.6 \pm 7.7$ & Tree & OG \\
\hline Blighia spp. & 33 & $9.16 \pm 6.95$ & 0.339 & $12.5 \pm 10.48$ & Tree & $\mathrm{ES}$ \\
\hline Uvariopsis congensis & 103 & $5.52 \pm 3.26$ & 0.331 & $7.61 \pm 6.27$ & Tree & OG \\
\hline Trema spp. & 3 & $27.91 \pm 27.59$ & 0.303 & $24.67 \pm 26.63$ & Tree & $\mathrm{ES}$ \\
\hline Erythrina abyssinica & 26 & $10.75 \pm 5.1$ & 0.287 & $10.54 \pm 8.9$ & Tree & ES \\
\hline Fagara angolensis & 11 & $12.73 \pm 13.67$ & 0.287 & $13.32 \pm 11.98$ & Tree & $\mathrm{ES}$ \\
\hline Teclea nobilis & 68 & $6.79 \pm 2.76$ & 0.287 & $9.9 \pm 14.42$ & Tree & MS \\
\hline Facaranda sp. & 34 & $7.85 \pm 2.67$ & 0.183 & $8.59 \pm 6.03$ & Tree & $\mathrm{EX}$ \\
\hline Aphania sp. & 23 & $8.94 \pm 4.6$ & 0.181 & $5.09 \pm 5.15$ & Tree & OG \\
\hline Tabernaemontana spp. & 29 & $7.05 \pm 4.24$ & 0.153 & $9.5 \pm 9.96$ & Tree & MS \\
\hline Pancovia turbinata & 1 & $43.93 \pm 0$ & 0.152 & $60 \pm 0$ & Tree & MS \\
\hline Diospyros abyssinica & 13 & $10.21 \pm 5.28$ & 0.133 & $19.46 \pm 16.25$ & Tree & MS \\
\hline Psidium sp. & 57 & $4.73 \pm 1.86$ & 0.115 & $2.24 \pm 3.14$ & Tree & $\mathrm{EX}$ \\
\hline
\end{tabular}

Table 3 Diameter and stage classification of extracted woody species along the boundary of Kibale National Park, Uganda (stages as defined in Table 2).

\begin{tabular}{|c|c|c|c|c|c|c|c|c|}
\hline \multirow[t]{2}{*}{ Diameter at cut } & \multicolumn{5}{|c|}{ Species type } & \multicolumn{2}{|c|}{ Total } & \multirow[t]{2}{*}{ Productive practice } \\
\hline & $\underset{\text { growth }}{\text { Old }}$ & $\begin{array}{c}\text { Mid- } \\
\text { successional }\end{array}$ & $\begin{array}{c}\text { Early } \\
\text { successional }\end{array}$ & Exotic & $\begin{array}{l}\text { Unknown } \\
\text { species }\end{array}$ & $n$ & $\%$ & \\
\hline$<10 \mathrm{~cm}$ & 306 & 100 & 699 & 635 & 298 & 2038 & 67 & Firewood and poles \\
\hline $10-19.9 \mathrm{~cm}$ & 56 & 28 & 254 & 293 & 70 & 701 & 23 & Poles \\
\hline $20-29.9 \mathrm{~cm}$ & 5 & 0 & 40 & 125 & 14 & 184 & 6 & Timber \\
\hline $30-39.9 \mathrm{~cm}$ & 6 & 0 & 16 & 40 & 4 & 66 & 2 & Timber and charcoal \\
\hline $40-49.9 \mathrm{~cm}$ & 5 & 1 & 7 & 5 & 2 & 20 & 1 & Timber and charcoal \\
\hline $50 \mathrm{~cm}$ and over & 4 & 3 & 13 & 4 & 2 & 26 & 1 & Timber and charcoal \\
\hline Total $(n)$ & 382 & 132 & 1029 & 1102 & 390 & 3035 & & \\
\hline Total (\%) & 13 & 4 & 34 & 36 & 13 & & & \\
\hline
\end{tabular}




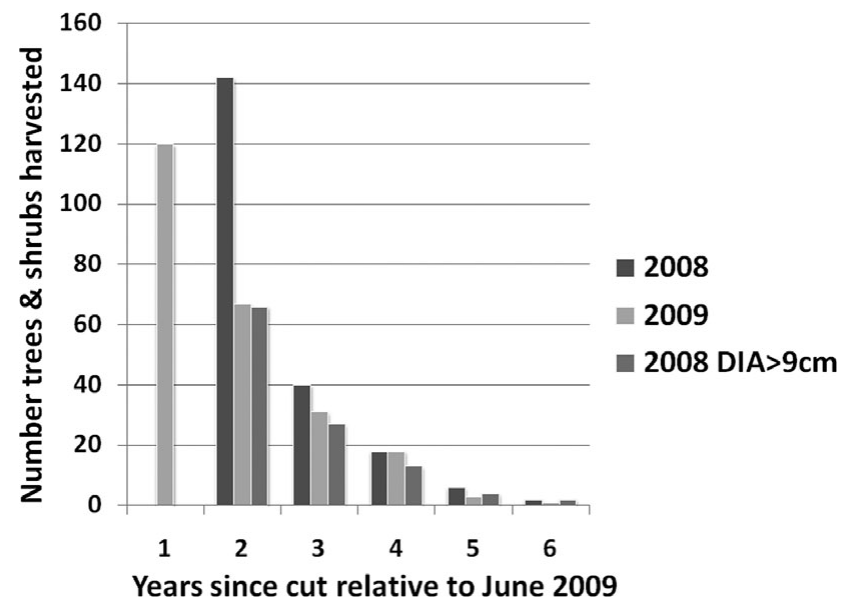

Figure 3 Temporal distribution of tree and shrub harvest. Boundary segments measured in both 2008 and 2009, covering 1.4 $\mathrm{km}$ of boundary and seven illegal trails.

Boundary data collected in 2008 indicated illegal tree extraction was increasing over time. Two boundary segments observed in 2008, covering $1.4 \mathrm{~km}$ of boundary and seven entry trails were revisited in 2009 (Fig. 3). Between visits, 120 trees had been extracted, $15 \%$ less than the off-take measured in 2008, with age of cut estimated at less than one year. Tree extraction recorded in 2008 and estimated to have occurred 0 12 months earlier compared well with tree extraction recorded in 2009 and estimated to have occurred 12-24 months prior, provided only trees $>9 \mathrm{~cm}$ diameter were included. This indicates smaller tree stumps were decaying over the year between measurements, a trend confirmed by the 2008 dataset of 3035 trees or shrubs, of which $35 \%$, cut more than one year prior, were $<9 \mathrm{~cm}$ in diameter, while $69 \%$ of the trees cut within one year of measurement were $<9 \mathrm{~cm}$ in diameter. Thus tree extraction does not appear to be increasing over time.

\section{Trails}

Ninety-nine human entry trails were found adjacent to 22 study villages, while three villages had no entry trails. Sixteen trails were legally sanctioned, although we still found evidence of illegal activities on these trails, namely tree harvesting, livestock grazing and two pit-fall animal traps. After removing legal trails, 73 remained (3.75 illegal entry trails per $\mathrm{km}$ of boundary observed). Trail length varied from $9 \mathrm{~m}$ to $362 \mathrm{~m}$, with an average length of $63.5 \mathrm{~m}$ (median $=47 \mathrm{~m}$ ). The distribution of illegal trails was not random (Moran's I = $0.12, \mathrm{Z}_{\text {score }}=3.29$ ), with the density of trails highest along the north-western boundary (Getis-Ord General G $=9.9$, $Z_{\text {score }}=2.75$ ), where up to 20 trails were observed along $1 \mathrm{~km}$ of boundary (Fig. 2b). The density of illegal entry trails was correlated with number of trees extracted $(\mathrm{r}=0.682, p<$ $0.001,25$ villages) because we often found tree harvesting at the end of entry trails.

\section{Animal poaching}

Twenty-four signs of poaching were found near six villages: 17 pit-fall traps, two snares and five snare holding depressions. The mean number of poaching signs per kilometre of boundary was 0.012 , but $62.5 \%$ were found along the north-eastern boundary (Fig. $2 c$ ). One survey respondent commented that people in his village always took meat from the Park, but they travelled far from the village to hunt, which would suggest poaching signs found during boundary observations under-represent actual levels of poaching for a given village.

\section{Livestock grazing}

Livestock grazing was observed in the Park near nine study villages: six goat herds ( $<20$ animals), and three large herds of cows (100-200 animals). On average, 19 livestock were seen grazing inside the Park per kilometre of boundary; however, $86 \%$ were observed in the southern half of the Park (Fig. $2 d$ ). Since boundary observation adjacent to a village occurred over 1-4 days, there was a concern livestock grazing in the Park might be under-observed, however, the number of observed livestock was predicted by the number of households reporting fines for grazing in the Park $\left(\mathrm{R}^{2}=0.566, p<0.001,25\right.$ villages). Therefore, we believe hotspots for grazing were identified by this study.

\section{Other disturbances}

Charcoal-making was observed inside or adjacent to the Park in five villages. Encroachment of the boundary to expand agricultural land was found in only one village, but there was disagreement about the location of the boundary and no visible demarcation. Finally, evidence of fire inside the Park was found adjacent to four villages. Two incidents were small $\left(<0.005 \mathrm{~km}^{2}\right)$ and not intentionally set: one from burning grass while maintaining a crop raiding protection trench and the other the result of a beehive catching fire. Two incidents were large $\left(>10 \mathrm{~km}^{2}\right)$, but discussion with UWA indicated these were started further away and therefore not attributable to the study villages.

\section{Demand for Park resources}

Non-response rates increased as questions about resource extraction became more direct. All respondents answered which resources they wanted access to, while three $(0.5 \%)$ declined to answer questions about the perceived benefit of resource extraction and $42(7 \%)$ declined to answer questions about admitted extraction of Park resources. The percentage of respondents admitting extraction was lower than the percentage desiring access to Park resources (Table 4). However, the percentage of respondents admitting extraction of a specific resource was aligned with the percentage wishing to harvest that resource $(\mathrm{r}=0.750, p=0.005,12$ resources $)$. 
Table 4 Resources wanted from Kibale National Park, Uganda and admission of illegal extraction. $\mathrm{n} / \mathrm{d}=$ no data collected. ${ }^{1} \mathrm{Residuals}$ of linear model $\left(\mathrm{R}^{2}=0.234\right)$ were spatially auto-correlated (Moran's $\mathrm{I}=0.2613, p<0.001$ ), after spatial lag correction $\mathrm{R}^{2}=0.464$. ' 'Other' includes creeping plants, palm leaves, handcraft materials, mushrooms, grasshoppers, sand, stones, clay, access to hot springs and access to land for cultivation.

\begin{tabular}{|c|c|c|c|c|c|c|c|c|c|c|c|c|c|}
\hline \multirow[t]{3}{*}{ Factor } & & \multicolumn{12}{|c|}{ Resources } \\
\hline & & \multicolumn{3}{|c|}{ Woody Biomass } & \multicolumn{6}{|c|}{ Non-timber forest products (NTFPs) } & \multicolumn{3}{|c|}{ Protein sources } \\
\hline & & Firewood & $\begin{array}{l}\text { Construction } \\
\text { poles }\end{array}$ & Exotic trees & $\begin{array}{l}\text { Medicinal } \\
\text { plants }\end{array}$ & Grasses & $\begin{array}{l}\text { Beehives } \\
\text { In park }\end{array}$ & Water & $\begin{array}{l}\text { Wild } \\
\text { coffee }\end{array}$ & Other $^{2}$ & Fishing & Bushmeat & $\begin{array}{l}\text { Livestock } \\
\text { grazing }\end{array}$ \\
\hline $\begin{array}{l}\text { \% respondents wanting } \\
\text { access }(n=596)\end{array}$ & & 89 & 83 & 59 & 82 & 66 & 62 & 60 & 47 & 11 & 43 & 31 & 56 \\
\hline $\begin{array}{l}\% \text { respondents admitting } \\
\text { access }(n=596)\end{array}$ & & 38 & 28 & $\mathrm{n} / \mathrm{d}$ & 28 & 17 & $\mathrm{n} / \mathrm{d}$ & 13 & $\mathrm{n} / \mathrm{d}$ & 4 & 7 & 5 & 8 \\
\hline $\begin{array}{l}\text { Wanted versus admitted } \\
\text { access (village mean, }\end{array}$ & $r$ & 0.553 & 0.356 & $\mathrm{n} / \mathrm{d}$ & & & 0.453 & & & & $0.493^{1}$ & 0.340 & 0.201 \\
\hline$n=25)$ & $p$ & 0.004 & 0.080 & & & & 0.023 & & & & 0.012 & 0.097 & 0.335 \\
\hline $\begin{array}{l}\text { Perceived benefit of } \\
\text { extraction versus }\end{array}$ & $r_{K}$ & 0.444 & 0.363 & $\mathrm{n} / \mathrm{d}$ & & & 0.374 & & & & 0.115 & 0.140 & 0.117 \\
\hline $\begin{array}{l}\text { admitted extraction } \\
\text { frequency }(n=596)\end{array}$ & $p$ & $<0.001$ & $<0.001$ & & & & $<0.001$ & & & & 0.006 & 0.001 & 0.005 \\
\hline $\begin{array}{l}\text { Wanted access versus } \\
\text { observed extraction }\end{array}$ & $r_{S}$ & 0.403 & -0.153 & 0.414 & & & $\mathrm{n} / \mathrm{d}$ & & & & $\mathrm{n} / \mathrm{d}$ & -0.090 & 0.320 \\
\hline (village mean, $n=25$ ) & $p$ & 0.046 & 0.466 & 0.039 & & & & & & & & 0.669 & 0.119 \\
\hline Observed extraction & & $\begin{array}{l}\text { Trees }<10 \mathrm{~cm} \\
\text { diameter }\end{array}$ & $\begin{array}{l}\text { Trees }<20 \mathrm{~cm} \\
\text { diameter }\end{array}$ & $\begin{array}{l}\text { Exotic trees (legal } \\
\& \text { illegal) }\end{array}$ & \multicolumn{6}{|c|}{ Extraction of NTFPs not measured } & $\mathrm{n} / \mathrm{d}$ & $\begin{array}{l}\text { Poaching } \\
\text { signs }\end{array}$ & $\begin{array}{c}\text { Livestock } \\
\text { grazing in } \\
\text { Park }\end{array}$ \\
\hline
\end{tabular}


Trees

The two most desirable resources were firewood and construction poles, consistent with $90 \%$ of measured tree extraction being of this size. Eighty-nine per cent of respondents wanted firewood, and this was evenly distributed around the Park, except along the north-western boundary, where only $77 \%$ of respondents wanted access to firewood and where a villager told us 'we desire nothing from the Park, because we have all the resources we need on our own land'. Demand for firewood was correlated with admitted extraction, and marginally with measured extraction of trees $<10 \mathrm{~cm}$ in diameter (Table 4). The percentage of households wanting exotic trees was positively correlated with measured legal plus illegal off-take of exotic trees (Table 4).

Extraction of firewood from KNP may be perceived as socially acceptable, especially since the highest admitted extraction was in two villages located adjacent to UWA outposts and, in both villages, we were told rangers occasionally allowed firewood collection within the Park and that in other villages rangers allowed access for special occasions. One ranger said, 'I cannot allow people to eat raw food when there is dead wood in the forest'.

Charcoal-making was reported in 10 villages, but only three coincided with villages where we found charcoal-making along the boundary. Brick-making was reported in 11 villages, while brick-making kilns were observed in 22 villages. The percentage of survey respondents making charcoal or bricks was not correlated with overall or large $(>20 \mathrm{~cm}$ diameter) tree extraction; however the percentage of households selling firewood did correlate with admitted firewood extraction $(\mathrm{r}=$ $0.641, p=0.001,25$ villages) and with measured extraction of trees between 10 and $20 \mathrm{~cm}$ in diameter $(\mathrm{r}=0.554, p=0.004$, 25 villages).

Villages where more respondents wanted access to firewood also had more woodlots ( $\mathrm{r}=0.401, p=0.047,25$ villages $)$, which in turn was correlated with tree extraction from the Park ( $\mathrm{r}=0.503, p=0.010,25$ villages), perhaps indicating people are planting trees in villages with higher demand for fuel wood, but that woodlots are not mitigating cost-free extraction from the Park. Use of energy-saving stoves was also higher in villages where more woodlots had been planted $\left(\mathrm{R}^{2}=0.311\right)$. Energy saving stoves were owned by 85 respondents living in 14 study villages, with $65 \%$ of users reporting they had halved their firewood consumption, while $25 \%$ said they used only one quarter of the wood they used before getting an energy saving stove.

\section{Non-timber forest products (NTFP)}

The next most wanted Park resources were medicinal plants $(82 \%)$, grasses $(66 \%)$, access to put beehives in the Park $(62 \%)$ and water $(60 \%)$. Respondents also wanted other NTFPs, such as wild coffee, creeping plants, palm leaves, handcraft materials, mushrooms, grasshoppers, sand, stones and clay. Ninety per cent of survey households wanted access to at least one NTFP, and $32.5 \%$ admitted entering the Park to collect them. Village averaged demand for and admitted extraction of NTFPs were correlated (Table 4).

Park access for medicinal plants appeared to be allowed. A villager told us 'we can request to pick medicine and it is usually accepted', but for all other resources 'if you enter the Park you are arrested'. Restricting access to NTFPs was perceived by some as removing their traditions, with one villager stating, 'Traditionally, Bakiga make papyrus plates, but now we have to use modern plates because we lack access to materials'.

\section{Animal poaching and fishing}

Thirty-one per cent of households wanted access to bushmeat, and 5\%, located in 17 villages, admitted entering the Park to hunt. A study in two southern villages estimated that almost $40 \%$ of households were engaging in illegal hunting, even though less than $2 \%$ admitted doing so (Solomon et al. 2007). Households in this study wanted bushmeat, a resident commenting that 'poachers sell bushmeat to people and it is very delicious'. Along the north-eastern boundary we were told by a village chairperson that 'people have lost a lot to [crop raiding] elephants and baboons, so locals go to the park to get meat'.

Seven per cent of households reporting a period of food insecurity in the prior year admitted taking meat from the Park. Seven households reported setting animal traps to protect their crops from wild animals, only two of which admitted taking meat from the Park. One government official did comment that, 'there may still be poor behaviours such as hunting that are culturally based', but we did not find any significant linkage between poaching and tribal affiliation.

Forty-three per cent of respondents wanted access to fish from Park lakes and 7\% admitted fishing inside the Park. Admitted fishing was correlated with demand for fish (Table 4) and with straight line distance from the village to the nearest lake within the Park $(r=-0.440, p=0.028,25$ villages).

\section{Livestock grazing}

Fifty-six per cent of respondents wanted to graze livestock in KNP, but only $8 \%$ admitted doing so. Villagers on the southern boundary of the Park admitted that during the dry season they grazed their cattle and went for water near the Park, and requested they be allowed access in times of drought. However the most frequent explanation for livestock grazing in the Park was that animals did not understand boundaries.

Around KNP, illegal grazing within the Park increased with cattle ownership. Cattle ownership was higher along the south-eastern Park boundary and the number of livestock observed in the Park was predicted by village averaged cow ownership $\left(\mathrm{R}^{2}=0.721, p<0.001,25\right.$ villages $)$. However, some respondents stated that they 'did not want to graze livestock in the Park because there is a risk of domestic animals contracting wild animal diseases', or 'the animals might be predated'. 


\section{Perceived benefit of extraction}

After removing 59 households that reported having resource access agreements, $76 \%$ of respondents said they did not benefit from extraction, $9.0 \%$ reported 'a little benefit', $7.7 \%$ 'some benefit', $4.0 \%$ 'a considerable benefit' and $3.1 \%$ benefited 'a lot'. When compared with household admitted resource extraction frequency, the results were all significant (Table 4), with the greatest contribution to perceived benefit coming from firewood, NTFP and construction pole extraction. Perceived benefit of extraction increased the closer a household was to the Park $\left(\mathrm{r}_{\mathrm{S}}=-0.210, p<0.001,536\right.$ households), as did the admitted frequency of extraction of firewood ( $\mathrm{r}_{\mathrm{S}}=-0.319, p<0.001,516$ households), poles $\left(\mathrm{r}_{\mathrm{S}}=-0.223, p<0.001,516\right.$ households) and NTFPs $\left(\mathrm{r}_{\mathrm{S}}=\right.$ $-0.211, p<0.001,516$ households), indicating extraction may be opportunistic for those who live close to the Park. Admitted frequency of grazing and poaching within the Park was not correlated with household distance from the Park.

\section{Resource access agreements}

Eight study villages had residents who participated in active RAs: beekeeping associations (five villages), drama and craft associations (two villages) and a fishing agreement (one village). To determine if RAs were improving conservation behaviours, basal area of harvested trees, number of poaching signs and number of livestock grazing in the Park were compared for villages with $(n=8)$ and without $(n=17)$ RAs. No significant difference was found when all types of RAs were considered ( $\mathrm{t}$-test, $p=0.688$ ), however, if only beekeeping RA villages $(n=5)$ were compared with all other villages $(n=$ 20 ), the level of illegal tree harvesting was significantly lower near villages with beekeeping associations ( $\mathrm{t}$-test, $p=0.006$ ). The protection of the Park by beekeepers was supported by a villager telling us that 'beekeepers guard the Park and stop others entering in case UWA thinks it is them that do any damage'. The beekeepers consider protecting the Park to be akin to protecting an investment because as one stated, 'hives situated inside the Park give better honey yields'. Members of these beekeeping associations make up to US\$250 per year, more than is made from crafts or fishing, suggesting that RAs can be effective, if the benefit to association members is sizable.

Some MOUs were with individuals who paid for access to harvest a specified exotic tree species. Other MOUs were with villages and did not require payment. Eight study villages had either individuals or communities with agreements to extract exotic trees. The number of exotic trees legally extracted by MOU correlated with the demand to access exotic timber ( $\mathrm{r}_{\mathrm{S}}=0.478, p=0.016,25$ villages), so many who want exotic trees are negotiating access. However, villages with MOUs also had higher illegal tree extraction (t-test, $p=$ 0.035 ) and a significantly higher number of the illegal harvest were unauthorized exotic tree species (Mann-Whitney $\mathrm{U}, p=$ 0.011). Most MOUs in the north were near tree plantations, planted when the Park was a forest reserve (Fig. 1). In the south, where FACE operations exist (Fig. 1), workers are permitted to take exotics home, but not everyone has access to the harvest. One villager said, 'it is unfair that only FACE workers get to take the trees. If they can have the exotics then so should I'. Illegal exotic tree extraction was higher when a village was closer to an old plantation or FACE operation $\left(r_{S}=\right.$ $-0.546, p=0.005,25$ villages). Access agreements, plantation logging history and the perception of unfair distribution of resources may allow people to perceive it is acceptable to harvest exotic trees.

\section{DISCUSSION}

Although human disturbance studies inside forested national parks are rare (Robbinset al. 2006), in East Africa, extraction of woody biomass is consistently identified as the most widespread disturbance (Bleher et al. 2006; Baranga 2007; Olupot et al. 2009). The most pervasive need for wood is for fuel (Dovie et al. 2004; Naughton-Treves et al. 2007), followed by poles for construction and hardwoods to make charcoal (Baranga 2007). This was also the case in KNP, with most extraction being trees or shrubs used for fuel wood and poles. Planting boundary trees did not reduce illegal extraction and boundary trees became another source for harvesting woody biomass.

The 'parks' conservation narrative, as typically described in the literature, would prescribe increased patrolling and fines for wood extraction (Terborgh \& van Schaik 2002), however increased enforcement to limit extraction of such a basic domestic need is seen by many as environmentally unjust (Abbot \& Mace 1999). The 'people' conservation narrative would argue that conservation cannot deny basic needs and would demand more access, to ensure communities can meet their subsistence requirements (Adams \& Hulme 2001). Woody biomass in KNP can accumulate rapidly after disturbance (Chapman, \& Chapman 1999), and extraction of early successional species may be beneficial for forest biodiversity (West et al. 2000). So the illegal tree extraction recorded in KNP may be sustainable, although a long term study would be required to confirm the regeneration rate after harvest and to understand if off-take increases as resources outside the Park diminish (Chhetri et al. 2003). However, current levels of illegal extraction exist with the threat of fines and arrests if perpetrators are caught. Given land outside the KNP is largely denuded of trees with the exception of forest fragments and individually owned woodlots (Hartter \& Ryan 2010), that extraction of fuel wood from these forest fragments is perceived as a right by most, even if the fragment belongs to an individual (Hartter \& Ryan 2010), and that legal access to woody biomass inside the Park appeared to increase illegal tree extraction, increasing community access to trees inside KNP is not a solution that will maintain habitat for biodiversity conservation.

Local people however need wood for fuel and construction, so it would be beneficial to develop strategies to support this need. Supplying tree seedlings, setting up woodlots and energy-saving stove programmes have been tried with 
success in some African countries (Stocking \& Perkin 1992; Barnes et al. 1994), and have been introduced in limited areas around KNP. The reported benefit of energy-saving stoves, highlight this option as one that should reduce firewood consumption, although stove efficiency can vary and actual firewood reduction may not be as significant as perceived by our respondents (Wallmo \& Jacobson 1998). If funding can be secured, UWA would like to provide tree seedlings to communities (UWA warden, personal communication 2009). Increased frequency of admitted tree extraction for households close to the KNP indicates tree seedling programmes should be spatially targeted towards the boundary. However, these programmes may not be adopted unless people perceive fuel wood is in short supply (Barnes et al. 1994), therefore increased policing along Park boundaries may be required in parallel with development options (Abbot \& Mace 1999), and illegal off-take should be monitored to determine if these initiatives are reducing illegal extraction while meeting the needs of communities.

Animal poaching by rural Africans is usually attributed to food insecurity, for protection against crop raiding or because the activity is traditional (Naughton-Treves 1998; Neumann 1998; Chapman et al. 2006). This 'people' conservation narrative, excusing hunting inside PAs as a survival response, was not supported by our research, as most households were not food insecure and were not trapping animals to defend against crop raiding. Therefore the policy of exclusion for animal poaching is warranted and is not counter to environmental justice. However, households losing crops to Park animals are disproportionally bearing the costs of conservation and compensation is warranted. However, this compensation is currently not affordable by local authorities. In recent years, much of the shared gate revenues have been targeted towards deep trenches to protect farmers from crop raiding and where these trenches exist, we observed lower levels of human disturbance inside the KNP, indicating this practice should be continued.

Collaborative resource management attempts to find a middle ground between the parks and people narratives, allowing local communities to sustainably access specific resources from the Park, while helping to police the Park for poachers (Adams \& Hulme 2001; Chhetri et al. 2003). Although these agreements do improve relations between UWA and the associations that enter into them, as evidenced by RA members reporting illegal activity to UWA (Chhetri et al. 2003), lower levels of illegal tree extraction were only found near communities with lucrative beekeeping associations, suggesting this conservation strategy should be applied to resources that create income generating opportunities rather than for extraction of subsistence resources.

\section{CONCLUSIONS}

Human disturbance indicators were found to cluster and be spatially coherent, identifying hotspots for extraction of particular resources. The most wanted and extracted resources were fuel wood and construction poles. Although the concentration of extraction on exotic and early successional tree species indicates current levels of extraction may be sustainable, increased access for local communities is not recommended because illegal wood extraction was higher adjacent to villages with agreements to legally extract wood. Instead development programmes to increase wood supplies outside the Park and to reduce the demand for fuel wood are encouraged.

Admitted poaching did not align with households experiencing food insecurity or using traps to protect against crop raiding animals. We did find livestock grazing in the Park to be higher where households owned more cows, a sign of wealth. Since lack of access to bushmeat and grasslands for cattle does not appear to hinder the livelihoods of the communities, our data support the policy of exclusion for animal hunting and in-park grazing.

Finally, illegal woody biomass extraction was low adjacent to villages where residents were members of beekeeping associations with legal access to the Park for beehive placement. Therefore, the implementation of resource access agreements with local community associations was found to be an effective means of reducing illegal tree extraction if association members profited substantially.

\section{ACKNOWLEDGEMENTS}

Catrina Mackenzie was funded by the Warren Development Geography Fund and McGill Faculty of Science African Field Work Award. Colin Chapman was funded by the Canada Research Chairs Program, the Wildlife Conservation Society, the Natural Science and Engineering Research Council of Canada, and the National Science Foundation. The Uganda National Council for Science and Technology, the Uganda Wildlife Authority and local leadership around KNP provided the permission for this research. We thank our Ugandan field assistants, Peter Ahabyona, Emmanuel Tumukugize, Seezi Tumukugize, Elizabeth Kamuli, and Tomas Mutegeki, for their work, all villagers who participated in this study, and Dr Joel Hartter, Dr Sebastien Breau and the anonymous reviewers for insightful comments on the manuscript.

\section{References}

Abbot, J.I. \& Mace, R. (1999) Managing protected woodlands: Fuelwood collection and law enforcement in Lake Malawi National Park. Conservation Biology 13: 418-421.

Adams, W.M. \& Infield, M. (2003) Who is on the gorilla's payrole? Claims on tourist revenue from a Ugandan National Park. World Development 31: 177-190.

Adams, W.M., Aveling, R., Brockington, D., Dickson, B., Elliot, J., Hutton, J., Roe, D., Vira, B. \& Wolmer, W. (2004) Biodiversity conservation and the eradication of poverty. Science 306: 11461149 .

Adams, W. \& Hulme, D. (2001) Changing narratives, policies and practices in African conservation. In: African Wildlife 
and Livelihoods: The Promise and Performance of Community Conservation, ed. D. Hulme \& M. Murphree, pp. 9-23. Oxford, UK: James Currey Ltd.

Ahrends, A., Burgess, N.D., Milledge, S.A., Bulling, M.T., Fisher, B., Smart, J.C., Clarke, G.P., Mhoro, B.E. \& Lewis S.L. (2010) Predictable waves of sequential forest degradation and biodiversity loss spreading from an African city. Proceedings of the National Academy of Sciences USA 107: 14556-14561.

Anselin, L. (1988) Spatial Econometrics: Methods and Models. Dordrecht, the Netherlands: Kluwer.

Archibald, K. \& Naughton-Treves, L. (2001) Tourism revenuesharing around national parks in western Uganda: early efforts to identify and reward local communities. Environmental Conservation 28: 135-149.

Baranga, D. (2007) Observations on resource use in Mabira Forest Reserve, Uganda. African Fournal of Ecology 45: 2-6.

Barnes, D.F., Openshaw, K., Smith, K.R. \& Van Der Plas, R. (1994) What makes people cook with improved biomass stoves? A comparative international review of stove programs. World Bank Technical Paper 242, Energy Series. Washington DC: World Bank.

Barrett, C.B. \& Arcese, P. (1995) Are Integrated ConservationDevelopment Projects (ICDPs) sustainable? On the conservation of large mammals in Sub-Saharan Africa. World Development 23: 1073-1084.

Barrow, E. \& Murphree, M. (2001) Community conservation: from concept to practice. In: African Wildlife and Livelihoods; The Promise and Performance of Community Conservation, ed. D. Hulme \& M. Murphee, pp. 24-37. Cape Town, South Africa: David Philip Publishers (Pty) Ltd.

Barve, N., Kiran, M.C., Vanaraj, G., Aravind, N.A., Rao, D., Uma Shaanker, R., Ganeshaiah, K.N. \& Poulsen, J.G. (2005) Measuring and mapping threats to a wildlife sanctuary in Southern India. Conservation Biology 19: 122-130.

Blair, E., Sudman, S., Bradburn, N.M. \& Stocking, C. (1977) How to ask questions about drinking and sex: response effects in measuring consumer behavior. Journal of Marketing Research 14: 316321.

Bleher, B., Uster, D. \& Bergsdorf, T. (2006) Assessment of threat status and management effectiveness in Kakamega Forest, Kenya. Biodiversity and Conservation 15: 1159-1177.

Brockington, D. (2002) Fortress Conservation: The Preservation of the Mkomazi Game Reserve, Tanzania. Oxford, UK: James Currey.

Brockington, D. \& Igoe, J. (2006) Evictions for conservation: a global overview. Conservation and Society 4: 424-470.

Bruner, A.G., Gullison, R.E., Rice, R.E. \& da Fonseca, G.A. (2001) Effectiveness of parks in protecting biodiversity. Science 291: 125 128.

Burgess, N.D., Balmford, A., Cordeiro, N.J., Fjeldsa, J., Kuper, W., Rahbek, C., Sanderson, E.W., Scharlemann, J.P.W., Sommer, J.H. \& Williams, P.H. (2007) Correlations among species distributions, human density and human infrastructure across high biodiversity tropical mountains of Africa. Biological Conservation 134: 164-177.

Buscher, B. \& Wolmer, W. (2007) The politics of engagement between biodiversity conservation and the social sciences. Conservation and Society 5: 1-21.

Cernea, M.M. \& Schmidt-Soltau, K. (2006) Poverty risks and national parks: policy issues in conservation and resettlement. World Development 34: 1808-1830.
Chapman, C.A. \& Chapman, L.J. (1999) Forest restoration in abandoned agricultural land: a case study from East Africa. Conservation Biology 13: 1301-1311.

Chapman, C.A. \& Lambert, J.E. (2000) Habitat alteration and the conservation of African primates: case study of Kibale National Park, Uganda. American fournal of Primatology 50: 169-185.

Chapman, C.A., Lawes, M.J. \& Eeley, H.A. (2006) What hope for African primate diversity? African Fournal of Ecology 44: 116-133.

Chhetri, P., Mugisha, A. \& White, S. (2003) Community resources use in Kibale and Mt Elgon National Parks, Uganda. Parks 13: $28-49$.

Child, B. (2004) Parks in Transition: Biodiversity, Rural Development and The Bottom Line. London, UK: Earthscan.

Colwell, R.K. (2009) Statistical estimation of species richness and shared species from samples [www document]. URL http://viceroy.eeb.uconn.edu/EstimateS

Dovie, D.B., Witkowski, E.T. \& Shackleton, C.M. (2004) The fuelwood crisis in southern Africa: relating fuelwood use to livelihoods in a rural village. Geofournal 60: 123-133.

Emerton, L. (1999) Balancing the Opportunity Costs of Wildlife Conservation for Communities around Lake Mburo National Park, Uganda. London, UK: International Institute for Environment and Development.

FACE the Future (2011) Kibale National Park [www document]. URL http://www.face-thefuture.com/en/projects/kibalenational-park-rehabilitation-project

Feeney, P. (1998) Accountable Aid: Local Participation in Major Projects. Oxford, UK: Oxfam.

Gadd, M.E. (2005) Conservation outside of parks: attitudes of local people in Laikipia, Kenya. Environmental Conservation 32: 50-63.

Gavin, M.C., Solomon, J.N. \& Blank, S.G. (2010) Measuring and monitoring illegal use of natural resources. Conservation Biology 24: 89-100.

Gillingham, S. \& Lee, P.C. (1999) The impact of wildlife-related benefits on the conservation attitudes of local people around the Selous Game Reserve, Tanzania. Environmental Conservation 26: 218-228.

Griffith, D.A. \& Layne, L.J. (1999) A Casebook for Spatial Statistical Data Analysis: A Compilation of Analyses of Different Thematic Data Sets. New York, NY, USA: Oxford University Press.

Haining, R. (2003) Spatial Data Analysis: Theory and Practice. Cambridge, UK: Cambridge University Press.

Hartter, J. (2009) Attitudes of rural communities towards wetlands and forest fragments around Kibale National Park, Uganda. Human Dimensions of Wildlife 14: 433-447.

Hartter, J. \& Goldman, A. (2011) Local responses to a forest park in western Uganda: alternative narrative on fortress conservation. Oryx 45: 60-68.

Hartter, J. \& Ryan, S.J. (2010) Top-down or bottomup?Decentralization, natural resource management, and usufruct rights in the forests and wetlands of western Uganda. Land Use Policy 27: 815-826.

Holmes, G. (2007) Protection, politics and protest: understanding resistance to conservation. Conservation and Society 5: 184-201.

Hutton, J., Adams, W.M. \& Murombedzi, J.C. (2005) Back to the barriers? Changing narratives in biodiversity conservation. Forum for Development Studies 2: 341-370.

Infield, M. (1988) Attitudes of a rural community towards conservation and a local conservation area in Natal, South Africa. Biological Conservation 45: 21-46. 
Infield, M., Naamara, A. \& Marquardt, M. (1993) The Socioeconomy, Natural Resource Use, and Attitudes Tomards the Park of Communities Living In and Around Lake Mburo National Park: Report of a Rapid Rural Appraisal. Kampala, Uganda: Makerere Institute of Social Research and Land Tenure Center.

Kideghesho, J.R., Roskaft, E. \& Kaltenborn, B.P. (2007) Factors influencing conservation attitudes of local people in Western Serengeti, Tanzania. Biodiversity and Conservation 16: 22132230.

Lebamba, J., Ngomanda, A., Vincens, A., Jolly, D., Favier, C., Elenga, H. \& Bentaleb, I. (2009) Central African biomes and forest succession stages derived from modern pollen data and plant functional types. Climate of the Past 5: 403-429.

Mbile, P., Vabi, M., Meboka, M., Okon, D., Arrey-Mbo, J., Nkongho, F. \& Ebong, E. (2005) Linking management and livelihood in environmental conservation: case of the Korup National Park, Cameroon. Fournal of Environmental Management 76: $1-13$.

McNeely, J.A. (1993) Economic incentives for conserving biodiversity: lessons for Africa. AMBIO 22: 144-150.

Mugisha, A. (2002) Evaluation of Community-based Conservation Approaches: Management of Protected Areas in Uganda. Gainsville, FL, USA: University of Florida.

Naughton-Treves, L. (1998) Predicting patterns of crop damage by wildlife around Kibale National Park, Uganda. Conservation Biology 12: 156-168.

Naughton-Treves, L. (1999) Whose animals? A history of property rights to wildlife in Toro, Western Uganda. Land Degradation and Development 10: 311-328.

Naughton-Treves, L., Buck Holland, M. \& Brandon, K. (2005) The role of protected areas in conserving biodiversity and sustaining local livelihoods. Annual Reviem of Environmental Resources 30: 219-252.

Naughton-Treves, L., Kammen, D.M. \& Chapman, C. (2007) Burning biodiversity: woody biomass used by commercial and subsistance groups in western Uganda's forests. Biological Conservation 134: 232-241.

Neumann, R.P. (1998) Impossing Wilderness: Struggles over Livelihood and Nature Preservation in Africa. Los Angeles, CA, USA: University of California Press.

Oates, J.F. (1999) Myth and Reality in the Rain Forest; How Conservation Strategies are Failing in West Africa. Los Angeles, CA, USA: University of California Press.

Olupot, W., Barigyira, R. \& Chapman, C.A. (2009) The status of anthropogenic threat at the people-park interface of Bwindi Impenetrable National Park, Uganda. Environmental Conservation 36: $41-50$.
Omeja, P.A., Chapman, C.A. \& Obua, J. (2009) Enrichment planting does not improve tree restoration when compared with natural regeneration in a former pine plantation in Kibale National Park, Uganda. African Fournal of Ecology 47: 650-657.

PAWAR (2009) PAWAR Study Areas. Kibale [www document]. URL http://atlas.whrc.org/pawar/default.aspx?Park=Kibale

Redford, K.H., Robinson, J.G. \& Adams, W.M. (2006) Parks as shibboleths. Conservation Biology 20: 1-2.

Robbins, P., McSweeney, K., Waite, T. \& Rice, J. (2006) Even conservation rules are made to be broken: Implications for biodiversity. Environmental Management 37: 162-169.

Scoones, I. (1995) Investigating difference: applications of wealth ranking and household survey approaches among farming households in Southern Zimbabwe. Development and Change 26: 67-88.

Solomon, J., Jacobson, S.K., Wald, K.D. \& Gavin, M. (2007) Estimating illegal resource use at a Ugandan park with the randomized response technique. Human Dimensions of Wildlife 12: $75-88$.

St John, F.A., Edwards-Jones, G., Gibbons, J.M. \& Jones, J.P. (2010) Testing novel methods for assessing rule breaking in conservation. Biological Conservation 143: 1025-1030.

Stocking, M. \& Perkin, S. (1992) Conservation-with-development: an application of the concept in the Usambara Mountains, Tanzania. Transactions of the Institute of British Geographers, New Series 17: 337-349.

Struhsaker, T.T. (1997) Ecology of an African Rain Forest. Gainsville, FL, USA: University of Florida Press.

Terborgh, J. \& van Schaik, C. (2002) Why the world needs parks. In: Making Parks Work: Strategies for Preserving Tropical Nature, ed. J. Terborgh, C. van Schaik, L. Davenport \& M. Rao, pp. 3-14. Washington, DC, USA: Island Press.

Treves, A. \& Karanth, K.U. (2003) Human-carnivore conflict: local solutions with global applications. Conservation Biology 17: 1489 1490.

Uganda Wildlife Statute (1996) FAOLEX. Food and Agriculture Organization of the United Nations Legal Office [www document]. URL http://faolex.fao.org/docs/texts/uga9000.doc

Wallmo, K. \& Jacobson, S.K. (1998) A social and environmental evaluation of fuel-efficient cook-stoves and conservation in Uganda. Environmental Conservation 25: 99-108.

West, A.G., Midgley, J.J. \& Bond, W.J. (2000) Regeneration failure and the potential importance of human disturbance in a subtropical forest. Applied Vegetation Science 3: 223-232.

Zanne, A.E. \& Chapman, C.A. (2005) Diversity of woody species in forest, treefall gaps, and edge in Kibale National Park, Uganda. Plant Ecology 178: 121-139. 